\title{
LOGISTICS OF TOURISM IN THE LOGISTICS OF SERVICES STRUCTURE: THEORY AND PRACTICE OF THE URBAN TOURISM CASE
}

\author{
Smyrnov I. G., Doctor of Science in Geography, Professor \\ Ukraine, Kyiv, Taras Shevchenko National University of Kyiv \\ DOI: https://doi.org/ 10.31435/rsglobal_ws/30112018/6235
}

\section{ARTICLE INFO}

Received: 12 September 2018

Accepted: 11 November 2018

Published: 30 November 2018

\section{KEYWORDS}

services logistics,

tourism logistics,

urban tourism,

complex logistics strategy,

sustainable development,

concept of tourist decentralization,

concept of reverse logistics.

\begin{abstract}
Theory and practice of tourism logistics in the logistics of services structure are opened. Essence of logistical integrated strategy of sustainable development of urban tourism, based on two concepts tourism decentralization and reverse logistics is outlined. The first concept is based on logistical organization of the tourist space of the city, which includes such components as: geologistical (geographical and logistical) identification of the resource base of urban tourism; logistical planning of tourist flows and determination of their needs; logistical design of tourist infrastructure; logistical design of supply chains of tourist infrastructure. The second concept involves an integrated approach to the recycling of the total amount of urban waste, including tourist one, taking into account their collection and removal from the city, as well as processing at special enterprises. The experience of Ukrainian cities of Lviv and Kyiv in this context is considered.
\end{abstract}

Citation: Smyrnov I. G. (2018) Logistics of Tourism in the Logistics of Services Structure: Theory and Practice of the Urban Tourism Case. World Science. 11(39). doi: 10.31435/rsglobal_ws/30112018/6235

Copyright: (C) 2018 Smyrnov I. G. This is an open-access article distributed under the terms of the Creative Commons Attribution License (CC BY). The use, distribution or reproduction in other forums is permitted, provided the original author(s) or licensor are credited and that the original publication in this journal is cited, in accordance with accepted academic practice. No use, distribution or reproduction is permitted which does not comply with these terms.

Introduction. Urban tourism nowadays is becoming more and more popular both in Ukraine and in the world. Urban turism has its own peculiarities connected with the high concentration of tourists on the limited territory of cities, especially their central and historical parts. In connection with this, there is a problem of tourist load increasing on the resource base of tourism in cities, which can lead to its deterioration and degradation. To solve this problem is possible by using integrated logistical approach to the sustainable development of urban tourism. Attention to this problem in the scientific literature for the time being is insufficient $[1 ; 2 ; 6]$, while in practical management of urban tourism development, this problem is already well-known and reflected in the development and adoption of relevant documents, for example, in city of Lviv, where the "Concept of Tourist Decentralization" was introduced recently $[3 ; 4 ; 5]$. The purpose of the research is to reveal the content, essence and features of complex logistical approach (strategy) to the sustainable development of urban tourism on the example of Ukrainian cities Kyiv and Lviv.

Results of the research. It should be noted that in this context the question arises about the essence of logistics of services flows (which include tourist services) and its differences in comparison with the logistics of commodity flows. In the latter case, everything is clear: there are manufacturers of goods and their consumers. Accordingly, goods are produced, stored, transported and consumed. Commodity flows thus become the flows of goods in their transportation, they can be felt, measured, stored, sent, received, consumed. If this is an international flow of goods, then it includes export and 
import, respectively, there are the exporting country with the point (port) of departure, the importing country with the point (port) of receipt and, possibly, the transit country through which transit commodities flow. Regarding the flows of services, the situation is different, what is determined by the features of the service as a commodity. So, the service is intangible, it can not be stored and warehoused, it is inseparable from the manufacturer and the consumer. Under such circumstances, talking about the flow of services is nonsense. It is possible to get out of this situation with the help of the "revolving" principle of logistics services proposed by the author [1, 32]. It reflects fact that in each type of services one should choose one main stream (MS) and several auxiliary streams (AS) using qualitative analysis method. For instant, in tourist services MS is one of tourists, AS informational, financial, personnel, material, commodity; in educational services MS - flow of students, AS - informational, personnel, financial, material; in trade services MS - flow of buyers, AS - commodity, informational, financial, personnel, material; in international trade MS - foreign trade flows (export, import), AS - customs-informational, customs-financial, personnel, material and technical; in transport services MS - traffic flow of the vehicles, AS - information, personnel, material. In this case, the volume of additional flows in relation to the main one is determined by the normative method, so there are certain norms regarding, for example, the number of teachers for a certain number of students etc. Each main flow passes through the appropriate host infrastructure with three variants of the logistics situation: a) the flow capacity is significantly lower than the capacity of the infrastructure; b) the flow capacity equals the capacity of the infrastructure; c) the flow capacity exceeds the capacity of the infrastructure. Of these three options, only the first one can be recognized as satisfactory, when the main stream freely passes through the receiving host infrastructure. The last two variants are not satisfactory, since queues arise because the flow can not go freely through the infrastructure (in case of option b) such situation is possible even with a slight increase of the MS power). In general, from the point of view of logistics, the occurrence of a queue indicates the emergence of a problem area in the flow of traffic, therefore, one of the tasks of logistics is the elimination of queues. For tourism, as well as for other branches of the services sphere, this provision remains important, that is, the only satisfactory situation (logistic model) is considered, when the MS (and this flow of tourists) freely passes through a tourist infrastructure or tourist object. But at the same time, the logistic model related to the services sector can have two varieties: soft and hard ones. The first means that in the case of an increase of MS there is a possibility of increasing infrastructure capacity. Such a model is typical, for example, for trade stores, when more buyers and payment points are opened with an increase in the number of buyers, and the flow of customers freely passes through cash desks. The other - a rigid model means the impossibility of increasing the capacity of the infrastructure whith the MS increasing. Under such conditions, in order to ensure the free flow passing, necessary measures for its regulation (restriction) are necessary. Such measures can be administrative (for example, traffic flow permission at certain time intervals) or of financial nature (setting a certain price for an "entrance ticket" for consumers). This model is typical for tourism and hotel and restaurant business. It is explained by the fact that each tourist object (resource) is unique, therefore, whith the growth of the tourist flow, it is not possible to switch it to another such object, because, for example, the Egyptian pyramids have no analogues, and another example Chomolungma, the highest mountain of the world in Nepal. In the case of hotel and restaurant business, each hotel and restaurant has a certain number of seats, and when they are all filled with guests (tourists), then it is not possible to accept any additional number of clients for a certain time. You can build a new hotel or restaurant, but it will take time.

So the logistic model used in tourism should have the form of a rigid logistical model in the service sector. Taking into account the specifics of tourism based on tourist resources, material and technical base (or infrastructure) and incoming tourist flows, it is possible to make a basic logistic model of tourism sustainable development, which includes three components (logistic potential of tourist resources (LP TR), logistic potential of material-technics bases of tourism (LP MTB) and the logistic potential of the incoming tourist flow (LP TF), which are connected together by the following formula: LP TR > LP MTB $\geq$ LP TF. In this model, the first part of the formula is a first-level protector for preserving tourist resources, and the second one, besides serving as a second-level protector, also provides business efficiency in the use of tourism resources. Also in this model information flows of two types are distinguished: 1) from LP TR to LP MTB (it's information regarding the maximum possible flow of tourists for a particular resource (object), provided to the state authorities (in our opinion, it must necessarily be indicated in the recreational passport of the resource (object); 2) from LP MTB to LP TF (it's the information which tour operators, that usually owns the material and technical base of tourism, provide for travel agencies - how many and what 
tours are offered for sale. In this model, the general indicator of sustainable (balanced) tourism development is the term of logistic potential, which in relation to recreational and tourist resources means the maximum possible number of visitors (tourists) for a certain period of time (day, month, season, year), which does not harm the state of tourism resource (object), environmental situation, provide necessary level of tourist comfort and do not harm way and conditions of local population life. It should be borne in mind that in case of exceeding the logistic potential of tourist resources there are various risks, among which the following are considered as the main ones: a) ecological (deterioration of the natural environment state); b) destructive (destruction of the tourist resource (object); c) medical (deterioration of self-feeling and health of tourists); d) guarding (exacerbation of the tourists safety problem). LP TR is recommended to be determined taking into account their division into naturalrecreational, cultural-historical, event and artificially created (each of them, in turn, is divided further and has peculiarities of logistic potential calculation).

The next variant of the logistic model of sustainable tourism is the expanded logistic model, which, on the one hand, links the regions with the demand for tourist services with the resource base of tourism, and on the other hand - the material and technical base of the tour operator with the production of related services and tourist goods in a particular region (destination) through which a certain tourist flow passes. The determining factor of this model is the tourism-resource potential of the region, which manifests itself through the logistics potential of the tourist resource and which determines the number of tours for tourists who (tours) and are sent to the regions for the demand for travel services sell. The optimal flow of tourists determined in such a way is coordinated, on the one hand, with the volume of production of related services (which includes ones of entertainment, trading, banking, insurance, rental etc.), and on the other hand - with the volumes of production of tourist goods (like souvenirs, products of folk art crafts, sports and tourist goods). The theoretical basis of the expanded logistic model is the application in tourism the well-known in logistics "PULLapproach", which consists in the fact that the volume of tourist flow in a certain tourist region (destination) should be regulated and determined by the logistic potential of the resource base of tourism, that is, do not exceed the maximum allowable level, after excess of which a variety of problems and risks that reduce the quality of recreation and the effectiveness of tourism is arised.

Finally, the third and last variant of the logistic model of sustainable tourism is a strategic one, whose purpose is to determine the type of logistic model of sustainable tourism development in the region. To do this, one should make a logistic assessment of tourism resources, determine the logistic potential of the resource base of tourism (LP RBT), determine the logistic potential of the material and technical base of tourism (LP MTB) and the logistic potential of the incoming tourist flow (LP TF). The next step is formation of logistics model of sustainable tourism development and defining of its varieties, which include: a) model of tourism development; b) crisis model; c) MTB development model. For the first variant of the model, the following equation is observed: LP RBT $>$ LP MTB $\approx$ LP TF; for the second variant: LP RBT $\leq$ LP MTB $\approx$ LP TF; for the third variant: LP RBT > LP MTB < LP TF. Thus, the model of tourism development corresponds to a situation in which the potential of the tourism resource base for reception of tourists significantly exceeds the capacity of the material and technical base of tourism and the corresponding tourist flow (LP MTB and LP TF in most cases are close values). This model recommends the surtain strategy and measures for tourism development through the development of the MTB and the strengthening of marketing and advertising activities to attract new tourists. Instead, the opposite - the crisis model variant arises when the potential of the resource base of tourism in relation for the reception of tourists decreases as a result of excessive tourist traffic, which is stimulated by increased capacity of the material and technical base. This model applies another strategy that includes measures to restrict the tourism development by deterring the construction of new MTB facilities and reducing the incoming flow of tourists. The important components of such a model also include ecological and educational measures aimed to preserve and restore the resource base of tourism and permanent it's control (monitoring of it's state). The last component is not unnecessary both in the model of tourism development and in the model of development of MTB (discussed below), in which it is also necessary to implement these measures in order to preserve and support sustainable tourism development in the long run. The third kind of model of sustainable tourism is the model of development of the material and technical base of tourism. It is currently observed mainly in post-Soviet countries (including Ukraine), when there is a powerful resource base of tourism and a significant tourist flows, but this lags behind the development of the material and technical base of tourism both by its size (capacity) and service quality (compearing with international and European standards). The logistic strategy of sustainable tourism 
for this model predicts, first of all, the urgent expansion of tourism MTB in the region, which can bring significant socio-economic effecti and business profits at low cost.

Tourism is now one of the most dynamic sectors of regions and cities economy. The urgent problems in this regard include the task of ensuring the sustainable development of tourism industry in cities. This is especially true for the most popular destinations among tourists, i.e. metropolitan and historic cities, which attract significant tourist streams. The latter means tourist load increasing on the existing cities' resource base of tourism, as well as on the whole urban economy, population, development and nature. In this context the task of tourism sustainable development in cities requires the consolidation of efforts of various scientific and practical directions, among which the important place belongs to tourism geography and logistics [1], that studies the flows phenomena in the tourism industry, highlighting the tourist traffic (flow of tourists) as the main stream, and financial, informational, commodity, personnel, material flows as servicing (additional) ones. The task of tourism logistics in the context of travel industry sustainable development is to regulate the main flow (i.e. tourist traffic), which would ensure the conservation of the tourism resource base in cities and in rural areas in order to further development of tourism activities. This problem is now quite noticeable not only in cities - the largest tourist centers of the world, but it is also acute in many cities of Ukraine. This concerns, first of all, Lviv, Kyiv, Odesa and other Ukrainian cities - popular tourist destinations. The problem of tourist overloading in Lviv is quite well-known recently, which was covered, in particular, in the author's publications [2, 195]. So, in our opinion, there is time for working out the complex logistical strategy of the tourism sustainable development in cities. This strategy, developed by the author, is based on two concepts. The first one is the concept of tourist decentralization, the second - the concept of reversible logistics. The first concept involves the need for an effective logistical organization of the city's tourist area (LO CTA). The main components of LO CTA are: 1) geologistical identification of tourism resource base; 2) logistical planning of tourist flows; 3) logistical design of tourism infrastructure; 4) logistical design of supply chains for tourism infrastructure objects $[2,200]$.

The first component covers geographical and logistical identification of city tourist resources. Geographical identification of tourism resource base means spatial localization of tourist objects of interest. They act as "tourist magnets", which attract tourist flows to a certain city area. So significant territorial concentration of tourist resources (objects) causes the concentration and overlap of tourist flows. These considerations should be taken into account when creating and placing new tourist objects (i.e. museums, monuments), which should not be "squeezed" to cities' central parts that are already overloaded with tourist objects of interest. So instead of excessive spatial concentration of tourist objects in cities' downtowns, their spatial dispersion is recommended by us. Logistical identification of tourist resources means the calculation of the logistical potential of each tourist object, that is, the maximum possible tourist flow, which will not affect tourism sustainable development and tourist resources state. It should be distinguished between the current number of tourists at the object, their number per day (taking into account the rotation coefficient), per month, per season, finally, per year. Geologistical identification is performed taking into account the division of tourist resources (objects) into: cultural-historical (monuments, museums, theaters etc.), architectural (historical and contemporary), events (various activities of public-cultural-entertaining nature).

The second component is based on determining the size and structure of tourist flows and their corresponding needs, which can be divided into first-order needs (benches, garbage cans, bio-toilets, street food, currency exchange etc.) and second-order needs (souvenirs, informational and advertising materials, press, touristic goods etc.).

The third component involves logistical design of tourism infrastructure network to meet the needs of tourists, in particular, first order needs (tourist infrastructure objects like points of street food, currency exchange offices etc.), second-order needs (tourist infrastructure objects like souvenirs shops, press and informational materials booths, tourist goods stores etc.) and the relevant logistics and transport infrastructure to meet the needs of the infrastructural facilities of the first and second orders, as well as collection and removal of waste. It should take into account the peculiarities of their placement in a certain city territory.

The fourth component involves the logistic design of supply chains to provide needs of first and second-order tourism infrastructure with the logistics and transport components in their composition, taking into account the particularity of their location in the city and the needs for collection and removal of tourist waste.

These issues are very relevant for Kyiv, where the increased tourist load on the resource base of the city's tourism has already led to cases of physical destruction of some of the most visited tourist 
objects. This applies not only to the old buildings of Kiev, but also to those that have been recently restored. Such cases include for example not only Samson's fountain on Podil, but also a monument to Magdeburg Law, located on the Embankment Highway, not far from Postal Square. It is also known as the Monument of Baptism of Ancient (Kyiv) Rus' or the Lower Monument to St. Volodymyr. The 18-meter-long column with a round gilded dome and cross on pedestal of pavilion-chapel with arches was installed in the distant 1802 by the project of the first Kyiv chief architect A.Melensky. The monument was erected in honor of the return of Magdeburg Law to city of Kyiv, which gave the city government wider powers. They gave him another meaning - it also meant the holy place from which the baptism of city of Kyiv and whole Ancient Rus' began. The fate of the monument proved to be difficult, and its appearance changed periodically. So, in nineteenth century in the middle of the pedestal there was a well with "holy water", and later octagonal fountain-bowl was installed here. In the Soviet era, the chapel was closed, and the cross from its top was removed. The monument has been repeatedly brought to an emergency, so it has experienced several restorations. Thus, to the 1000th anniversary of the baptism of Kyiv Rus' in 1988 the cross was returned to the column, and an underground passage to the Dnieper-river was built nearby. Last time the global reconstruction of the monument was made - to the 1025th anniversary of the Baptism of Kyiv Rus' in 2013: monument became white, and in the middle of the pavilion a chapel and a fountain-bowl with a crane in the form of a "golden" cross were restored. Only 5 years have passed away and now one can see an absolutely obscure picture: inside the pavilion is dirty, the fountain does not work, the crane is absent. In addition, the inscriptions left by the vandals are painted on the column and on the pedestal. Despite this, the monument still impresses with its beauty and grandeur. After visiting the monument to Magdeburg Law, tourists are advised to go down to the underground passageway. It also deserves attention. On the one side, above the entrance, a cross is depicted with inscription: "Here in 988 A.D. in the confluence of the waves of the Dnieper-river and Pochayna-river Kyiv Rus' was Baptized " (some letters, however, already fell apart). On the other side of the passageway, from the side of the Dnieper, in the shallow niches in the wall there are two bas-reliefs - figures of John the Baptist and Kyiv Crown Prince Volodymyr the Great both surrounded by angels. All this appeared in 2013. Interior of the passageway was the masterpiece in itself: on its walls students of Kyiv Art School depicted fragments of the map of Kiev in the X-XIII centuries with Lyadsky Gate and Sofiyivsky Cathedral. But, unfortunately, wildness has won spirituality: now maps in the passageway are no longer there, and every millimeter of walls and even partially of the ceiling is filled with inscriptions made by "unknown artists", with most of inscriptions are frankly obscene. By the way, in 2014, another monument should appear at the site, as indicated on a sign near the bas-reliefs. There was even a competition announced and the best option was chosen - a wooden font on the water like a cross measuring 22.6 by $31.4 \mathrm{~m}$. But the object never appeared.

As for Lviv, there are fewer such cases (perhapse, due to the quality of historical Austrian construction), but nevertheless they are also. There are many other problems in the city of Lviv, the main one now is the removal of rubbish. After the fire at Gribovychy landfill in the summer of 2016, Lviv did not know where to move out its waste, the volume of which naturally grew with the growth of tourists number. No wonder, that the tourist record of Lviv (2.6 million tourists in 2017 - the first place among the Ukraine cities) coincided with the "rubbish crisis" in this city. So using of the second concept i.e. reverse logistics aims to provide a comprehensive recycling of the total amount of urban waste, in particular, solid household (SHW). Generally speaking it's necessary to separate the actual municipal waste and one that is the result of the tourists stay. The proof that tourist waste occupies a significant share in the citywide waste volume is its peak increases, particularly in cities central districts, after any holidays (at one third a minimum). For example, from the center of Kiev after the final match of the Champions League on May 26, 2018 more than 212 tons of garbage were taken in just one day!

It should be noted that there is a certain specifics of the problem of garbage collection in the city, its removal and processing. Thus, garbage collection has its peculiarities depending on the distance of the district from the center; the waste removal from the city can be carried out either to landfills, or to incineration and waste recycling plants; finally, the waste treatment at the waste processing enterprises means the location of the latters within or outside the city, as well as their belonging to specialized establishments or other industries such as pulp and paper (PPM) and card and paper mills (CPM), glass factories, etc. Knowledge of the pulp and paper and glass-making industries' geography can help in solving of the problem of waste removal from the city and garbage processing. So, near Lviv is located Zhydachiv PPM, and near Kyiv - the Obukhiv CPM and Gostomel' glass factory, which buy a significant part of raw materials (up to one third) abroad. And at that time both 
cities of Lviv and Kyiv have big problems with the removal and processing of solid household (including waste paper) and other (including glass and plastic bottles) types of waste.

Let's note that the tourist left behind a lot of waste, especially in the city center. It is the direct waste. In addition to it, there is indirect waste, it is a waste of hotels, restaurants, cafes, which in the center of Lviv in recent years appeared a lot. This waste also requires efficient collection, removal and processing technologies - such possibility is provided by "reverse logistics". In Lviv, the need to place trash cans near each bench in the center was taken into account (garbage cans were artistically designed and made by local craftsmen), but no ways were found for the removal of solid waste and its subsequent processing. Meanwhile, the daily amount of waste in the city of Lviv is 600 tons. As we can see, it is possible to solve the garbage problem in Lviv on basis of two approaches, i.e. transport and logistical. Until recently, the first approach prevailed in the city, which was to find transport intermediaries (companies), which were obliged (for a very decent payments) to find suitable landfills and take out urban waste from Lviv. But, as experience showed, when Lviv garbage got into almost all areas of Ukraine, it did not solve the problem of waste removal. And only recently the city leadership turned to a logistic approach, i.e. the use of "reverse" logistics, when not only input streams to the city (including tourists, goods, raw materials, fuel etc.) were analyzed, but also city output streams were subject to analysis, among them waste streams. Logistical science and practice have developed proposals for efficient management of these flows and their deep processing at special enterprises (waste processing plants). Such enterprises can be built in relatively short time and the corresponding investments can be both international and internal. Such experience is represented by Kyiv, where the waste volume is 3000 tons per day, but their storage and processing is successfully carried out, firstly, at the landfill site near Pidhirtsi village; secondly, at the Bortnychy Aeration Station (BAS); and thirdly, at the incineration plant "Energy" in Darnitsa. Kyiv actively attracts international achievements and investments, so BAS is being modernized with the participation of Japanese companies, and in the city of Fastov, a plastic waste recycling plant was constructed with Chinese participation (accordingly, several plastic picking points were opened in Kyiv). The next idea of the new technology of street waste control the Mayor of Kyiv V.Klychko brought from a business trip to Berlin. This is the installation of underground garbage cans, which will gradually replace the usual old-style containers for garbage. In such way, the old urns that are still "working" in the Ukraine capital and did not meet the needs of Kyiv residents and guests of the city will be replaced with new modern ones.

One more problematic aspect connected with a sharp increase in the number of tourists in Lviv is one that was warned by American experts who helped to develop The Tourist Concept of Lviv: as soon as tourism begins to develop dynamically, among the guests of the city there will appear those who came here for intimacy. A similar way was taken by many cities, which were relying on tourism. Annually, according to UNWTO, in the world more than $3 \mathrm{mln}$ people travels in order to receive sexual services, and the turnover of this "industry" is estimated at an amount of up to \$ 100 billion. Of course, sex tourism develops mainly in poor countries where rich tourists travel for the certain purposes [2, 241-250]. The popular Italian edition La Repubblica devoted an entire article to the modern sexual destinations of the world, among which, along with Thailand, Brazil, Cambodia, Cuba, Bangladesh, Colombia and Bulgaria, Ukraine is also mentioned. And until recently, Ukrainian cities, where intim-tourism traditionally existed, as La Repubblica considers, were Odesa, Kyiv and Kharkiv. Lviv joined them relatively recently, although before the World War II it was a service city with hotels, restaurants, casinos. "It was then a kind of European Las Vegas" - says about Lviv the famous city restaurateur Andriy Hudo, co-founder of the Holding of Emotions "! FEST". With the development of tourism and resort infrastructure, the city of Lviv is once again returning to the prewar economic structure, and this fact is of concern to some Lviv residents. A. Khudo also notes that the flow of sex tourists to Lviv has sharply increased since the last devaluation of hryvnia, when the rest in Ukraine became accessible even to foreigners with modest revenues [3]. "Promotes" this process the rapid development of the city's tourist infrastructure in recent years with many luxury hotels, clubs and restaurants, as well as its geographical proximity to the EU countries, their visa-free regime with Ukraine, increasing diversity of flights to Lviv from many countries, including budget airlines. Under these conditions, in our opinion, the task of the authorities and representatives of the national and regional tourism industry is that Ukraine (and in particular its largest cities like Kyiv, Lviv, Odesa, Kharkiv etc.) has to be associated first of all with historical and architectural values, natural resources, gastronomy and culture.

One can ask, what is connection whith logistics here? Answer is the next: the purpose of logistics is to study the flow processes in the economy in order to optimize them. Economic flows (including flows of tourists) connect such parts of the market as demand and supply. Actually supply 
applies marketing and advertising technologies to charm consumers to attract their demand. On the other hand, as we know, when there is demand, there will be supply. But if there is no supply and its marketing support is absent, then demand will decrease accordingly, or it will disappear altogether. Applying these considerations to the situation with intimate tourism in Lviv and other major tourist centers of Ukraine, one can predict that if there is no appropriate infrastructure in the form of night clubs, gentleman clubs, strip bars etc. and their active advertising companies, then the flows of tourists-consumers of this "tour-product" will be much smaller.

Conclusions. The dynamic development of urban tourism, which has recently been observed in Ukraine and in the world, raises a number of problems, among which one can note the tourist overload of cities, especially their central and historical parts; destruction many historical and architectural objects and monuments; increase in the amount of urban waste, including tourist one; cases of intimate tourism etc. Solutions most of these problems are possible on the base of the integrated geologistical approach. So this approach, applied in the "Concept of Tourist Decentralization of the City of Lviv", should be extended to all other aspects of the city's tourism industry, including waste management, using the latest technologies and attracting national and international investments. This proposal applies not only to Kyiv and Lviv, but also to other cities significant tourist centers of Ukraine, namely, Kharkiv, Dnipro, Odesa etc.

\section{REFERENCES}

1 Smyrnov I. G., Tourism Logistics :Text-book/ I.G.Smyrnov.-K .: Znannia, 2009. - 444 p.

2 Smyrnov I. G. Marketing in Tourism : Text-book / I.G.Smyrnov. - K .: KNU named after Taras Shevchenko, 2016. - 251 p.

3 Each community has a tourism potential [Electronic resource]. - access mode: http:// decentralization.gov.ua /news/9242.

4 Ivanova E. 50 shades of Lviv / E. Ivanova // Novoye vremia strany. - № 19. - May 24, 2018. - P.38-41.

5 Tulchinskaya M. Beautiful country, but they love her not for this / M. Tullchinskaya / / Correspondent. 2018. - May 11, No. 9 (801). - P.40-43.

6 Smyrnov I.G. Integrated logistic approach to the sustainable development of urban tourism / I.G., Smyrnov // Tourism and hospitality: state, problems, perspectives: mater. IV International scientific-practical conference. - Cherkasy: ChNU named after Bogdan Khmelnitsky / Publisher Tretyakov O, M., 2018. P.80-85. 